\title{
Unveiling Social Gratifications Sought and Obtained from Social Media Utilization
}

\author{
Ridwan Adetunji Raji ${ }^{1}$, Olawale Abdulgaffar Arikewuyo², Adeyemo Saheed \\ Oladimeji Adeyemi ${ }^{3}$, Muhammad Ramzan Pahore ${ }^{4}$ \\ ${ }^{1}$ College of Communication and Media Sciences, Zayed University, Abu Dhabi, \\ United Arab Emirates \\ ${ }^{2}$ Department of Mass Communication, University of Ilorin, No. C2, Fate Tanke Rd, \\ Ilorin, Kwara State, Nigeria \\ ${ }^{3}$ Department of Journalism, School of Communication, Lagos State University, Lasu \\ Main Road Ojo Campus, 102101, Lagos, Nigeria \\ ${ }^{4}$ Department of Media and Communication Studies, University of Sindh, Jamshoro- \\ 76080, Sindh, Pakistan \\ *Corresponding author, e-mail: rajiridwanadetunji@gmail.com
}

\begin{abstract}
Going by the proposition of the Uses and Gratifications Theory (UGT), people are motivated to use media by various psychological factors and for obtaining different forms of gratifications. However, as social media continue to play an essential role in shaping the sociability and bridging social connectivity and interactions among its users, therefore, this study seeks to incorporate social influence and social interactions as the social gratification sought in social media utilization, as well as both bonding and bridging social capital as social gratification obtained from social media utilization. An online survey was conducted among 400 users of Instagram in Nigeria. The data analyzed with PLS-SEM revealed that social influence and social interaction significantly motivate social media utilization. Also, social media utilization is significantly associated with bonding and bridging social capital. Impliedly, this study shows that social media is a social and networking tool which is stimulated by social factors and for achieving social purposes such as getting help, support and community engagements.
\end{abstract}

Keywords: Social Media Utilization, Social Gratifications, Social Capital, Social Influence, Social Interactions.

\section{Introduction}

Social media has become a global platform that influences every stratum of human endeavour ranging from health (McKee et al., 2013), education (Greenhow \& Cathy, 2014), politics (Markham, 2016), social interactions (Ji et al., 2016) to advertising (Gupta et al., 2017). Going by the proposition of the Uses and Gratifications Theory (UGT), people are motivated to use media by various psychological factors and for obtaining different forms of gratifications (Dunne et al., 2010; Ledbetter et al., 2016). Hence, UGT proposes that certain factors motivate users to use social media to fulfil their informational, social, and personal desires (Dunne et al., 2010; Phua et al., 2017). For instance, Quan-Haase and Young (2010) found that social influence and social interactions are critical motivating factors to use social media. Therefore, as social media continue to play an essential role in shaping the sociability and bridging social connectivity and interactions among its users (Cheung et al., 2010; Donath \& Boyd, 2004; Phua et al., 2017), it is therefore important to focus on the social motivations and social gratifications obtained by using social media.

Furthermore, studies on media experience have demonstrated that among other reasons why people use social media, social factors are the most significant reasons 
motivating the usage of social media (Dewan \& Ramaprasad, 2014; Eggers et al., 2017; Xiang \& Gretzel, 2010). Also, Phua et al. (2017) revealed the possibility of bridging and bonding social capital among users in the United States through different social media platforms including; Facebook, Twitter, Instagram and also Snapchat. More so, besides that UGT provides cogent explanations on both the motivating factors and also gratifications of social media utilization which have been employed to study media users mainly in the developed countries, limited studies have emerged from developing countries such as Nigeria.

Meanwhile, the continuous surge of Internet access among Nigerians has not only increased the ease of connectivity, interaction and communication but has also boosted a new sense of belonging and responsibilities towards community building, social cohesions and social capital development among the growing number of Nigerians who are social media users. Meanwhile, social media most especially Instagram, is fast becoming a go-to platform for soliciting, obtaining and offering any kinds of help ranging from financial, political, health and a wealth of informational resources. Therefore, this study draws on the on-going debate on social capital development through the Internet (Appel et al., 2014; Campbell \& Kwak, 2010; Robinson \& Martin, 2010) to examine the impact of social motivations (social influence and social interactions) on social media utilization. Also, this paper sets out to discern the role of social media utilization in bridging and bonding social capital among Instagram users in Nigeria.

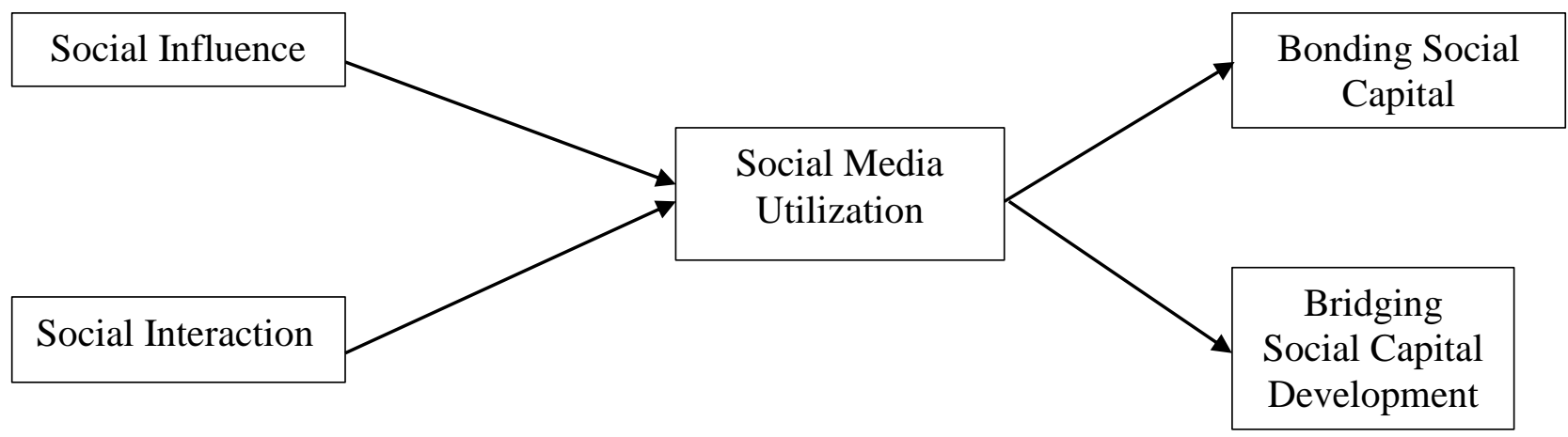

Uses and Gratifications Theory

Figure 1. Proposed Theoretical Model

The Uses and Gratifications Theory (UGT) is based on establishing an understanding of the motivations towards media uses and the gratifications sought and obtained by the audience (E. Katz et al., 1974) For instance, 'During the 1970s, Uses and Gratifications theorists intently examined audience motivations and developed additional typologies of the uses people made of the media to gratify social and psychological need' (Ruggiero, 2009). The Uses and Gratifications Theory when traced historically originated as a television theory, however, with modern-day technological developments; the theory has shifted to become dominant when conducting studies on social media (Whiting \& Williams, 2013). The theory also clarifies the motivations behind the selection of a media platform, channel, and content over others. UGT accords a conscious state of mind to the people based on their wants and needs, which in many instances facilitates their choice of media and content (Elihu Katz, 1957). For instance, accessibility, social connection, interaction, and attention may be regarded as some of the motivation behind the use of social media in the current era we live. (J. Katz, 1987) elucidates that media users are active and conscious of their needs and demands, thereby necessitating their choice of media and content. He explains further that media users are also able to dissect the content 
of the media thus necessitating the need to classify the theory as a limited effect theory of the media. Due to the availability of a fleet of media platforms, UGT explains that media audience can choose what gratifies their present needs and desires, as such; this sets a template for competition and the need to satisfy their audience among the media platforms (Rathnayake \& Winter, 2018).

Interestingly, the Uses and Gratifications Theory has become a toast of new media scholars especially social media researchers (Larose \& Eastin, 2004). This is because of its applicability and compatibility with the studies. For example, research has shown that based on the gratification sought by users especially on social media, they have consistently been referred to as an active audience. The theory further explains that the media audience processes the power to select based on taste and choice (Elihu Katz et al., 1973). As such, a particular media or channel cannot compel the audience to consume specific content. This further explains the rationale behind the concept of zipping and zapping where the audience may switch platform or pass a message if they so desire. Uses and Gratifications Theory accords premium on the level of consciousness of the users stating that the users are significantly aware of what media content they wish to consume, at what time, and through which channel (Elihu Katz et al., 1973).

Though, the Uses and Gratifications Theory elucidates an array of gratifications sought and obtained using the media, Urista, Dong, and Day (Urista et al., 2009) explain further that 'web searching, the acquisition of information, the ability to engage in interpersonal communication, and socialization'. This affirms its link with the social media and its perfect role in providing social engagements and support. However, the surge in the number of social media platforms available to the audience has granted unlimited access to gratifying users' needs (Gruzd et al., 2017). Quite many studies have investigated the uses of social media in gratifying needs and desires (Larose \& Eastin, 2004; Louis Leung \& Wei, 2000; Luo, 2002). However, this study charts a new part with its investigation of how social media use facilitate gratifications in bridging and bonding social capital of social media users.

Bridging and Bonding Social Capital on Social Media

Social capital has been connected to a collection of positive social results, for example, better general well-being; reduced rates of wrongdoings, and increased financial assistance (Adler \& Kwon, 2002). Whenever social capital decreases in a community, its people often encounter expanded social issue, lessened participation in civic activities, and conceivably lack of interest and connection with their communities. Putnam (2001) differentiates between bridging and bonding of social capital. Bonding social capital refers to 'the resources accessible from one's closest, most homogenous social relationships' (Appel et al., 2014) Meanwhile, bridging social capital refers to the resources that are accessed through external networks and relationships (Lin \& Erickson, 2008; Putnam, 2000).

Hence, as social media connections cut across close relationships between family members as well as 'feeble ties' otherwise known as free associations between people who may not have recognizable connections, it provides easy links to both bonding and bridging social capitals. In other words, the social interactions and friendship ties that are facilitated through social media utilization are important for bridging and bonding social capital in the form of attending to informational needs, community building, individual productivity (Ellison et al., 2011; Helliwell \& Putnam, 2004; Wellman et al., 2001) and most recently financial help which in the social media parlance known as 'Give Away'. Therefore, with the aid of social media, social capital has further been boosted as a means 
of sharing or distributing social and informational resources (Hossein \& Nia, 2017). Unarguably, social media has been ascribed to promoting effective and efficient social capital development (Geber et al., 2016). This is based on its ability to bring together people of the same ideology from different parts of the world through a common platform. With social media, time, place, and circumstance do not matter; as such, this is a valuable tool in enhancing social capital development (Ellison et al., 2007).

Proposed Theoretical Model

The proposed theoretical model presented in Figure 1 draws on the proposition of UGT to establish the social gratifications sought and obtained from social media utilization. In line with the UGT-based theorists (Haddock \& Zanna, 1999; Perugini \& Bagozzi, 2001; Phang et al., 2009) people are motivated to use media by several psychological factors (gratification sought) as well as to satisfy some psychological needs (gratification obtained) which include personal, social and tension release. Meanwhile, considering the social characteristics of social media, this study focuses only on social gratifications as the major gratification sought and obtained from social media usage. The proposed model sets out to fill two major gaps. First is that previous UGT-based studies have demonstrated that, various gratifications are sought and obtained from various media. In other words, the characteristics of a media inform the types of gratifications that could be sought and obtained from it.

In the case of social media being an exclusive media for establishing and developing social ties, achieving social purposes and accessing different dorms of social recourses, previous studies have not delved into the social gratifications which are stimulating social media utilization. Therefore, this study argues that social gratifications (social influence and social interaction) mainly influence social media utilization. Based on the argument proffered by Katz et al. (1974) that media users are motivated by their sense of belonging and their aspiration to be part of a group. Hence, social media users are expected to be motivated by the thought of being active participants in their social connections (Zolkepli et al., 2018) Therefore, both social influence and social interaction are expected to motivate social media utilization (Bagozzi et al., 2007; Kaye \& Johnson, 2002; L Leung, 2001; Quan-Haase \& Young, 2010). Secondly, previous researchers on social interactions and connections that are established online or through social media and social capital have demonstrated a two-sided argument. At one hand, some researchers contended that the Internet is connected to the decline in social capital. For instance, Nie (2001) argued that Internet usage diverts people from face-to-face interactions and subsequently reduce their access to social capital.

Furthermore, some other scholars asserted that online participation complement or substitute personal interactions and reduce participation in physical and geographical community engagement (Hampton \& Wellman, 2003; Kavanaugh et al., 2005; Wellman et al., 2001). At the other hand, researchers have also established the significance of internet-based connections and interactions for the establishment of strong and feeble ties that provide the basis of bridging and bonding social capital (Campbell \& Kwak, 2010; Resnick, 2001). These researchers argued that bridging and bonding social capital can be improved through the flexible and virtual social connections which permit participants to invent and sustain bigger, diversified relationship networks that they can obtain resources from (Donath \& Boyd, 2004; Resnick, 2001; Siapera \& Veglis, 2012; Wellman et al., 2001). Donath and Boyd (2004) added that social media technologies have significantly improved, created and sustained different types of relationships and connections and offered improved access that is not delimited by geographical locations to bridging and 
bonding social capital among participants of social networks. Therefore, this study seeks to broaden the knowledge by incorporating social influence and social interactions as the social gratification sought in social media utilization as well as both bonding and bridging social capital as social gratification obtained from social media utilization.

\section{Methods}

An online survey was conducted among 400 Instagram users in Nigeria. The measurements for the variables in this study were adapted from past studies with strongly established validity and reliability. In specifics, five items were adopted for social influence, social interaction respectively and eight items adopted for measuring social media utilization from Zolkepli, Kamarulzaman \& Kitchen, (2018). Items for measuring both bonding and bridging social capital were adapted from Ellison, Steinfield, Lampe, (2007). Five Likert-type scales ranging from 1 'Strongly Disagree' to 5 'Strongly Agree' is used to anchor responses for all the items.

Famous Nigerian socialites shared the URL link to the questionnaire among their Instagram followers for closely two months. From the 400 received responses, 323 were found valid after eliminating uncompleted responses and deleting outliers. Both SPSS and PLS-SEM were employed to analyse the data collected for this study. SPSS was used to effectuate the preliminary analysis including descriptive statistics, normality, outlier and multicollinearity. Subsequently, the PLS-SEM using was used for the development of to the measurement model and the structural model of the proposed theoretical model in Figure 1.

\section{Results}

The distribution of the respondents reveals that majority of the respondents are young adults as $90.7 \%$ are between the ages of 20 to 30 years and only $8.7 \%$ are older than 31 years of age. Also, there are more male respondents $(50.8 \%)$ than female respondents $(49.2 \%)$ in this study. With regards to the educational background of the respondents, a vast percentage of the respondents has Diploma/College certificates (56.7\%). Also, $27.9 \%$ and $13.9 \%$ of the respondents have Bachelors' degree and postgraduate degree respectively. The data also mirrors a typical mixture of religion in the Nigerian society as $54.8 \%$ of the respondents are Christians and $44.3 \%$ are Muslims. Meanwhile, less than $1 \%$ of the respondents have no religion. Even though the majority of the respondents are residents of South Western part of Nigeria (48.9\%), the distribution of the respondents in this study spread across the six geopolitical regions of the country. Finally, the descriptive analysis shows the respondents as active users of Instagram as nearly all of them $(88.8 \%)$ have more than 500 followers on their Instagram pages. Also, it was also revealed that, different types of ties or associations which include; old friends (37.2\%), Strangers (23.8\%), Acquaintances (23.2\%), School/College mates (13.9\%) and Siblings $(1.9 \%)$ are knotted through Instagram.

Meanwhile, this section presents measurements of the results of online surveys, and structural models from PLS-SEM. For the measurement model, Table 1 and Table 2 present the result of the measurement model including Composite Reliability (CR), Average Variance Extracted (AVE), Convergent Validity and Discriminant validity (Hair et al., 2014). 
Table 1. Internal Consistency and Convergent Validity

\begin{tabular}{|c|c|c|c|c|}
\hline Construct & Items & Loading & AVE & $\mathrm{CR}$ \\
\hline \multirow[t]{4}{*}{$\begin{array}{l}\text { Social } \\
\text { Influence }\end{array}$} & $\begin{array}{l}\text { People around me have influenced me to } \\
\text { use Instagram. }\end{array}$ & 0.641 & 0.520 & 0.811 \\
\hline & $\begin{array}{l}\text { People on around me think to have me as } \\
\text { friends on Instagram would let me stay in } \\
\text { contact with them. }\end{array}$ & 0.817 & & \\
\hline & $\begin{array}{l}\text { People around me think I should have an } \\
\text { account on Instagram. }\end{array}$ & 0.712 & & \\
\hline & $\begin{array}{l}\text { People around me think it would be great if my } \\
\text { name can be found on their friend's list. }\end{array}$ & 0.704 & & \\
\hline \multirow{4}{*}{$\begin{array}{l}\text { Social } \\
\text { Interaction }\end{array}$} & Instagram is a place to socialize. & 0.708 & 0.523 & 0.814 \\
\hline & I express myself freely on Instagram. & 0.716 & & \\
\hline & $\begin{array}{l}\text { I fit in a group of people that share the same } \\
\text { interests on Instagram. }\end{array}$ & 0.732 & & \\
\hline & I get more points of view on Instagram. & 0.737 & & \\
\hline \multirow[t]{7}{*}{$\begin{array}{l}\text { Social Media } \\
\text { Utilization }\end{array}$} & $\begin{array}{l}\text { I expect my Instagram usage to increase } \\
\text { in the future. }\end{array}$ & 0.598 & 0.509 & 0.877 \\
\hline & My usage of Instagram has benefited my life. & 0.807 & & \\
\hline & My usage of Instagram has impacted my life. & 0.823 & & \\
\hline & $\begin{array}{c}\text { My usage of Instagram has substantially } \\
\text { changed my life. }\end{array}$ & 0.732 & & \\
\hline & $\begin{array}{l}\text { My usage of Instagram is extensive; therefore, I } \\
\text { continue to utilize it. }\end{array}$ & 0.583 & & \\
\hline & $\begin{array}{l}\text { Overall, I adopt Instagram because of } \\
\text { its usefulness. }\end{array}$ & 0.760 & & \\
\hline & $\begin{array}{c}\text { Overall, I am satisfied with my usage } \\
\text { of Instagram. }\end{array}$ & 0.649 & & \\
\hline \multirow[t]{4}{*}{$\begin{array}{l}\text { Bonding Social } \\
\text { Capital }\end{array}$} & $\begin{array}{l}\text { There are several people on Instagram I trust to } \\
\text { help solve my problems. }\end{array}$ & 0.754 & 0.538 & 0.822 \\
\hline & $\begin{array}{l}\text { The people I interact with on Instagram would } \\
\text { put their reputation on the line for me. }\end{array}$ & 0.677 & & \\
\hline & $\begin{array}{l}\text { The people I interact with on Instagram would } \\
\text { be good job references for me. }\end{array}$ & 0.806 & & \\
\hline & $\begin{array}{l}\text { The people I interact with on Instagram would } \\
\text { help me fight an injustice. }\end{array}$ & 0.689 & & \\
\hline \multirow[t]{8}{*}{$\begin{array}{l}\text { Bridging Social } \\
\text { Capital }\end{array}$} & $\begin{array}{c}\text { Interacting with people on Instagram makes me } \\
\text { interested in things that happen outside } \\
\text { of my town. }\end{array}$ & 0.668 & 0.504 & 0.890 \\
\hline & $\begin{array}{c}\text { Interacting with people on Instagram makes me } \\
\text { want to try new things. }\end{array}$ & 0.698 & & \\
\hline & $\begin{array}{l}\text { Talking with people on Instagram makes me } \\
\text { curious about other places in the world. }\end{array}$ & 0.699 & & \\
\hline & $\begin{array}{l}\text { Interacting with people on Instagram makes me } \\
\text { feel like part of a larger community. }\end{array}$ & 0.772 & & \\
\hline & $\begin{array}{l}\text { Interacting with people on Instagram makes me } \\
\text { feel connected to the bigger picture. }\end{array}$ & 0.766 & & \\
\hline & $\begin{array}{l}\text { Interacting with people on Instagram reminds } \\
\text { me that everyone in the world is connected. }\end{array}$ & 0.669 & & \\
\hline & $\begin{array}{l}\text { I am willing to spend the time to support } \\
\text { general Instagram community-related activities. }\end{array}$ & 0.745 & & \\
\hline & Interacting with people on Instagram gives me & 0.653 & & \\
\hline
\end{tabular}


new people to talk to.

Note: The result of the measurement model including Composite Reliability (CR), and Average Variance Extracted (AVE)

Table 2. Discriminant Validity

\begin{tabular}{cccccc}
\hline Variables & BOSC & BRSC & SIF & SIT & SMU \\
\hline Bonding Social Capital (BOSC) & 0.733 & & & & \\
Bridging Social Capital (BRSC) & 0.244 & 0.710 & & & \\
Social Influence (SIF) & 0.162 & 0.152 & 0.721 & & \\
Social Interaction (SIT) & 0.353 & 0.370 & 0.434 & 0.723 & \\
Social Media Utilization (SMU) & 0.504 & 0.535 & 0.379 & 0.549 & 0.713 \\
\hline
\end{tabular}

Note: The square root of the AVE are marked in italics

Table 3 presents the result of the path coefficient and the decision for every path in the model. The findings revealed that, all the path of the proposed model are significant (Social Influence (SIF) $\rightarrow$ Social Media Utilization (SMU), $\beta=0.173, p<0.05$; Social Interaction (SIT) $\rightarrow$ Social Media Utilization (SMU), $\beta=0.474, p<0.05$; Social Media Utilization (SMU) $\rightarrow$ Bonding Social Capital (BOSC), $\beta=0.504, p<0.05$; Social Media Utilization (SMU) $\rightarrow$ Bridging Social Capital (BRSC), $\beta=0.535, \mathrm{p}<0.05$ ).

Table 3. Path Coefficient Assessment

\begin{tabular}{ccccc}
\hline Hypotheses & Direct Effect $(\beta)$ & T-Statistics & P-Values & Decision \\
\hline SIF -> SMU & 0.173 & 3.407 & 0.001 & Supported \\
SIT -> SMU & 0.474 & 9.645 & 0.000 & Supported \\
SMU -> BOSC & 0.504 & 15.579 & 0.000 & Supported \\
SMU -> BRSC & 0.535 & 13.156 & 0.000 & Supported \\
\hline
\end{tabular}

Note: The result of the path coefficient and the decision for every path in the model

\section{Discussion}

This study validates a theoretical model which incorporates both social gratifications sought regarding social influence and social interaction as well as social gratifications obtained, bridging and bonding social capital from social media utilization. In other words, the result of this study shows that users of social media are significantly motivated by their families, friends and people around to have an account and keep in contact through social media. Additionally, this study evinced that, social media users are significantly motivated by the opportunity of interacting freely with friends, family and with a group of friends with similar viewpoints (Fitrianti et al., 2020; Indriani \& Prasanti, 2019). Therefore, this study corroborates with previous UGT-based studies that people employ social media to satisfy their psychological needs which include social factors (Bagozzi et al., 2007; Kaye \& Johnson, 2002; L Leung, 2001; Quan-Haase \& Young, 2010).

In furtherance, this study established a significant association between the utilization of social media and social capital. To put the findings of this in the perspective of the UGT, the theoretical model validated in this study affirms that both bonding and bridging social capital are significant social gratifications that users obtained from the utilization of social media. As for bonding social capital, this study shows that the use of social media--in this case, Instagram--offers users the opportunity to interact with trusted friends and acquaintances who can help them solve any problems, put their reputations in line when necessary and help them fight injustice. Furthermore, social media utilization increases the chances of bridging social capital especially by providing the perfect 
platform which makes it users get interested in topical issues in and out of their communities. Also, it offers them the opportunity to try new things, allows users to develop an interest in their communities and feel connected with their local communities and the entire world in general.

The results presented in this study have some theoretical and practical implications. Theoretically, this study incorporates both bonding and bridging social capital as important social gratifications obtained from social media utilization. Also, the results presented in this study, therefore, affirms the social characteristics of social media by focusing on both social gratifications sought and social gratifications obtained from social media utilization. Additionally, this study contributes by providing an empirical pattern of how social media is increasingly becoming an important platform for accessing and developing social capital above and beyond the notion that, social capital is decreasing the access to social capital in communities (Arikewuyo et al., 2019).

Practically, this study contributes by revealing that social media utilization is not just increasingly providing access to social capital but also expanding the definitions of social capital. For example, social capital is extending beyond social resources between a group of people who socialize together, engage in the same community development activities and among those who carry out their religious obligations together to being an inter-related or a multi-level access to social capital development. As such, it is established that through social media usage, people have access to bonding social capital in weak social ties and vice versa (Arikewuyo et al., 2018)

Finally, the findings of this study provide evidence that both social interaction and social influence are two important variables that significantly impact the usage of social media in this case; Instagram. Although not directly, the implication of social interaction and social infleince on social media usage also reinforce the role of electronic word-ofmouth and online reviews which have both been established to be invaluable for the development and maintenance of long-term and trustworthy business-related relationship. In other words, the result of this study therefore corroborates previous findings on the importance of focusing on social interactions and social influence of potential customers for the sustainability of business-related relationships over social media.

\section{Conclusion}

Conclusively, this study empirically demonstrates the significant roles of social interactions and social influence in motivating users of social media. Also, this study establishes both bonding and bridging social capital as significant consequences of social media utilization. Therefore, the result presented in this study shows that social media is a social and networking tool which is stimulated by social factors and for achieving social purposes such as getting help, support and community engagements (Arikewuyo, EfeÖzad, et al., 2020; Arikewuyo, Eluwole, et al., 2020). Meanwhile, this study has only employed a quantitative approach, so future researchers are recommended to explore the notion of social capital in the context of the divergent social networks that are continuously enabled through social media with using a qualitative method.

\section{Conflict of Interest}

We certify that there is no conflict of interest with any financial, personal, or other relationship with other people or organizations related to the material discussed in the manuscript. 


\section{Acknowledgements}

The authors would like thank to the social media users who helped shared our questionnaire on their pages. Also, we appreciate the respondents of the study (400 Instagram users in Nigeria), for their responses during the time of the survey.

\section{References}

Adler, P. S., \& Kwon, S.-W. (2002). Social Capital: Prospects for a New Concept. The Academy of Management Review, 27(1), 17-42.

Appel, L., Dadlani, P., Dwyer, M., Hampton, K., Kitzie, V., Matni, Z. A., Moore, P., \& Teodoro, R. (2014). Testing the validity of social Capital Measures in the study of information and communication technologies. Information, Communication \& Society, 17(4), 398-416.

Arikewuyo, A. O., Efe-Özad, B., \& Lasisi, T. (2019). Erotic use of Social Media Pornography in Gratifying Romantic Relationship Desires. The Spanish Journal of Psychology, 1(2), 1-20.

Arikewuyo, A. O., Efe-Özad, B., \& Owolabi, A. (2020). I U': A Semiotic Analysis of Romantic Relationship Bitmojis on Social Media. In It Happened on Tinder: Reflections and Studies on Internet-Infused Dating (pp. 134-144). Institute of Network Cultures. https://www.researchgate.net/publication/338178515_I_U'AA_SEMIOTIC_ANA LYSIS_OF_ROMANTIC_RELATIONSHIP_BITMOJIS_ON_SOCIAL_MEDIA

Arikewuyo, A. O., Eluwole, K. K., \& Ozad, B. (2020). Influence of Lack of Trust on Romantic Relationship Problems: The Mediating Role of Partner Cell Phone Snooping. Psychological Reports, 12(10), 1-10.

Arikewuyo, A. O., Ozad, B., \& Saidu, A. (2018). Use of Social Media in Establishing Virtual Relationship among select University Students. Novena Journal of Communication, 6 .

Bagozzi, R. P., Dholakia, U. M., \& Pearo, L. R. K. (2007). Antecedents and Consequences of Online Social Interactions. Media Psychology, 9(1), 77-114.

Campbell, S. W., \& Kwak, N. (2010). Mobile communication and social capital. New Media \& Society, 12(3), 435-451.

Cheung, M. K. C., Chiu, P. Y., \& Lee, M. K. O. (2010). Online Social Networks: Why Do Students Use Facebook? Computers in Human Behaviour, 27(4), 1337-1343.

Dewan, S., \& Ramaprasad, J. (2014). Social Media, Traditional Media, and Music Sales. MIS Quarterly, 38(1), 101-121.

Donath, J., \& Boyd, D. (2004). Public displays of connection. Bt Technology Journal, 22(4), 71-82.

Dunne, Á., Lawlor, M. A., \& Rowley, J. (2010). Young People's Use of Online Social Networking Sites - A Uses and Gratifications Perspective. Journal of Research in Interactive Marketing, 4(1), 46-58.

Eggers, F., Hatak, I., Kraus, S., \& Niemand, T. (2017). Technologies That Support Marketing and Market Development in SMEs - Evidence from Social Networks. Journal of Small Business Management, 55(2), 270-302.

Ellison, N. B., Steinfield, C., \& Lampe, C. (2007). The benefits of Facebook "“Friends:"” social capital and college students' use of online social network sites. Journal of Computer-Mediated Communication, 12, 1143-1168.

Ellison, N. B., Steinfield, C., \& Lampe, C. (2011). Connection Strategies: Social Capital Implications of Facebook-Enabled Communication Practices. New Media \& 
Society, 13(6), 873-892. https://doi.org/10.1177/1461444810385389

Fitrianti, A., Febriana, K. A., \& Ersyad, F. A. (2020). Personal branding Cino Fajrin through Instragram. Jurnal The Messenger, 12(1), 74-83.

Geber, S., Scherer, H., \& Hefner, D. (2016). Social capital in media societies: The impact of media use and media structures on social capital. International Communication Gazette, 78(6). https://doi.org/10.1177/1748048516640211

Greenhow, C., \& Cathy, L. (2014). Social media and education: reconceptualizing the boundaries of formal and informal learning. Journal Learning, Media and Technology, 41(1), 6-30. https://doi.org/10.1080/17439884.2015.1064954

Gruzd, A., Valle, M. E. Del, Haythornthwaite, C., \& Paulin, D. (2017). Social Media in Educational Practice: Faculty Present and Future Use of Social Media in Teaching. Hawaii International Conference on System Sciences. https://doi.org/10.24251/HICSS.2017.019 .

Gupta, H., Singh, S., \& Sinha, P. (2017). Multimedia tool as a predictor for social media advertising- a YouTube way. Multimedia Tools and Applications, 76, 1855718568. https://doi.org/10.1007/s11042-016-4249-6

Haddock, G., \& Zanna, M. P. (1999). Affect, Cognition, and Social Attitudes. In W. Stroebe \& M. Hewstone (Eds.), European Review of Social Psychology (pp. 75100). Wiley.

Hampton, K., \& Wellman, B. (2003). Neighboring in Netville: How the Internet supports community and Social Capital in a wired suburb. City \& Community, 2(4), 277311.

Helliwell, J. F., \& Putnam, R. D. (2004). The social context of well-being. Philosophical Transactions of the Royal Society, 359(1449), 1435-1446.

Hossein, \& Nia, F. H. (2017). A New Method of Rural E-Business, Information and Communication Technology (ICT) Development in India. International Journal of Networks and Communications, 3(2), 33-39. https://doi.org/10.5923/j.ijnc.20170702.01

Indriani, S. S., \& Prasanti, D. (2019). Understanding multiculturalism in family on Whatapp group in the distruption era. Jurnal The Messenger, 11(2), 209-219.

Ji, Q., Raney, A. A., Losh, S. C., Sypher, U., \& Merle, P. F. (2016). Watching with Virtual Crowds: The Popularity, Motivation, and Effect of Live Posting during Entertainment TV Viewing [Florida State University]. http://purl.flvc.org/fsu/fd/FSU_2016SP_Ji_fsu_0071E_12840

Katz, E., Blumler, J. G., \& Gurevitch, M. (1974). Utilization of Mass Communication by the Individual. In J. G. Blumler \& E. Katz (Eds.), The Uses of Mass Communication: Current Perspectives on Gratifications Research. Sage.

Katz, Elihu. (1957). The Two-Step Flow of Communication: An Up-To-Date Report on an Hypothesis. Political Opinion Quarterly, 21(1), 61-78. https://doi.org/10.1086/266687

Katz, Elihu, Gurevitch, M., \& Haas, H. (1973). On the Use of the Mass Media for Important Things. American Sociological Review, 38(2), 164-181.

Katz, J. (1987). What makes crime 'news'? Media Culture \& Society, 9(1). https://doi.org/10.1177/016344387009001004

Kavanaugh, A., Carroll, J. M., Rosson, M. B., Zin, T. T., \& Reese, D. D. (2005). Community networks: Where offline communities meet online. Journal of Computer-Mediated Communication, 10(4).

Kaye, B., \& Johnson, T. (2002). Online and in the Know: Uses and Gratifications of the 
Web for Political Information. Journal of Broadcasting \& Electronic Media, 46(1), $54-71$.

Larose, R., \& Eastin, M. S. (2004). A Social Cognitive Theory of Internet Uses and Gratifications: Toward a New Model of Media Attendance. Journal of Broadcasting \& Electronic Media, 48(3), 358-377.

Ledbetter, A. M., Taylor, S. H., \& Mazer, J. P. (2016). Enjoyment Fosters Media Use Frequency and Determines its Relational Outcomes: Toward a Synthesis of Uses and Gratifications Theory and Media Multiplexity Theory. Computers in Human Behavior, 54(149-157).

Leung, L. (2001). Gratifications, Chronic Loneliness and Internet Use. Asian Journal of Communication, 11(1), 96-119.

Leung, Louis, \& Wei, R. (2000). More Than Just Talk on The Movie: Uses and Gratifications of The Cellular Phone. Journalism and Mass Communication Quarterly, 77(2), 308.

Lin, N., \& Erickson, B. H. (2008). Theory, measurement, and the research enterprise on social capital. In N. Lin \& B. H. Erickson (Eds.), Social capital. An international research program. Oxford University Press Inc. https://doi.org/10.1093/acprof:oso/9780199234387.003.0010U

Luo, X. (2002). Uses and Gratifications Theory and E-Consumer Behaviors. Journal of Interactive Advertising, 2(2), 34-41. https://doi.org/10.1080/15252019.2002.10722060

Markham, T. (2016). Review essay: Social Media, Politics and Protest. Media Culture \& SOciety, 38(6), 946-957. https://doi.org/10.1177/0163443716665101

McKee, A. C., Stern, R. A., Nowinsk, C. J., Stein, T. D., Alvarez, V. E., Daneshvar, D. H., Lee, H.-S., Wojtowicz, S. M., Hall, G., Baugh, C. M., Riley, D. O., Kubilus, C. A., Cormier, K. A., Jacobs, M. A., Martin, B. R., Abraham, C. R., Ikezu, T., Reichard, R. R., Wolozin, B. L., ... Cantu, R. C. (2013). The spectrum of disease in chronic traumatic encephalopathy. Brain, 136(1), 43-64. https://doi.org/10.1093/brain/aws307

Nie, N. H. (2001). Sociability, interpersonal relations, and the Internet: Reconciling conflicting findings. American Behavioral Scientist, 45(3), 420-435.

Perugini, M., \& Bagozzi, R. P. (2001). The Role of Desired and Anticipated Emotions in Goal-Directed Behaviours: Broadening and Deepening The Theory of Planned Behaviour. British Journal of Social Psychology, 40, 79-98.

Phang, C. W., Kankanhalli, A., \& Sabherwal, R. (2009). Usability and Socialability in Online Communities: A Comparative Study of Knowledge Seeking and Contribution. Journal of The Association for Information Systems, 10(10), 721747.

Phua, J., Jin, S. V., \& Kim, J. J. (2017). Gratifications of Using Facebook, Twitter, Instagram, or Snapchat to Follow Brands: The Moderating Effect of Social Comparison, Trust, Tie Strength, and Network Homophily on Brand Identification, Brand Engagement, Brand Commitment, and Membership Intentio. Telematics and Informatics, 34(1), 412-424.

Putnam, R. D. (2000). Bowling Alone. Simon \& Schuster.

Quan-Haase, A., \& Young, A. L. (2010). Uses and Gratifications of Social Media: A Comparison of Facebook and Instant Messaging. Bulletin of Science, Technology \& Society, 30(5), 350-361.

Rathnayake, C., \& Winter, J. S. (2018). Carrying Forward the Uses and Grats 2.0 Agenda: 
An Affordance-Driven Measure of Social Media Uses and Gratifications. Journal of Broadcasting \& Electronic Media, 62(3), 371-389. https://doi.org/10.1080/08838151.2018.1451861

Resnick, P. (2001). Beyond bowling together: Sociotechnical capital. HCI in the New Millennium, 77, 247-272.

Robinson, J. P., \& Martin, S. (2010). IT use and declining social capital? Social Science Computer Review, 28(1), 45-63.

Ruggiero, T. E. (2009). Uses and Gratifications Theory in the 21st Century. Mass Communication and Society, 3-337. https://doi.org/10.1207/S15327825MCS0301_02

Siapera, E., \& Veglis, A. (2012). The Handbook of Global Online Journalism. John Wiley \& Sons, Inc.

Urista, M. A., Dong, Q., \& Day, K. D. (2009). Explaining why young adults use MySpace and Facebook through uses and gratifications theory. Human Communication, 12, 215-299.

Wellman, B., Haase, A. Q., Witte, J., \& Hampton, K. (2001). Does the Internet Increase, Decrease, or Supplement Social Capital? Social Networks, Participation, and Community Commitment. American Behavioral Scientist, 45, 436-455.

Whiting, A., \& Williams, D. L. (2013). Why people use social media: A uses and gratifications approach. Qualitative Market Research, 16(4).

Xiang, Z., \& Gretzel, U. (2010). Role of Social Media in Online Travel Information Search. Tourism Management, 31(2), 179-188. https://doi.org/10.1016/j.tourman.2009.02.016

Zolkepli, I. A., Kamarulzaman, Y., \& Kitchen, P. J. (2018). Uncovering psychological gratifications affecting social media utilization: A multiblock hierarchical analysis. Journal of Marketing Theory and Practice, 26(4), 412-430. 